\title{
PEMODELAN INTERPRETASI STRUKTURAL PENGEMBANGAN KAWASAN PESISIR DAN PULAU-PULAU KECIL DI TELUK WEDA
}

\author{
Interpretative Structural Modeling of \\ Coastal and Small Island Development in Weda Bay
}

\author{
"Martini Djamhur', Mennofatria Boer², Dietriech G Bengen² dan Achmad Fahrudin ${ }^{2}$ \\ ${ }^{1}$ Mahasiswa SPL IPB \& Staf Dosen FPIK Universitas Khairun, Ternate. \\ ${ }^{2}$ Dosen FPIK Institut Pertanian Bogor, Bogor \\ *email: thien_02@yahoo.com; martinidjamhur@gmail.com \\ Diterima 1 Nopember 2013 - Disetujui 3 Nopember 2014
}

\begin{abstract}
ABSTRAK
Pemodelan dalam pengembangan kawasan pesisir dan pulau-pulau kecil di Teluk Weda bertujuan untuk mengkaji bentuk kelembagaan bagi pengelolaan kawasan pesisir dan pulau-pulau kecil dengan menggunakan metode Interpretative Structural Modeling (ISM) telah dilakukan pada daerah Teluk Weda, Kabupaten Halmahera Tengah. Hasil analisis Interpretative Structural Modeling (ISM) menyimpulkan bahwa kelembagaan pengelolaan yang perlu dipertimbangkan untuk mewujudkan pembangunan kawasan pesisir dan pulau-pulau kecil di Teluk Weda yang berkelanjutan adalah pemerintah, wisatawan, dan perguruan tinggi lewat pengembangan wisata. Upaya yang harus dilakukan adalah meningkatkan produktifitas pemanfaatan sumberdaya alam, mutu produk perikanan dan jumlah permodalan kegiatan perikanan tangkap dengan membantu nelayan dalam menentukan harga perikanan, mengelola sumberdaya alam, peraturan investasi daerah dan membuat kebijakan yang konsisten memegang peranan penting pada pengembangan kawasan pesisir dan pulau-pulau kecil di Teluk Weda. Implikasi kebijakan yang perlu dilakukan yaitu: membuat peraturan daerah yang dapat menunjang kegiatan; mensosialisasikan undang-undang yang telah ditetapkan pemerintah; melakukan pelatihan yang menyangkut undang-undang yang telah ditetapkan pemerintah; mempertahankan peraturan dan adat istiadat yang masih ada sesuai dengan pengelolaan kawasan dan membentuk kelompok swadaya masyarakat yang berkaitan dengan penetapan kawasan.
\end{abstract}

Kata Kunci: pemodelan interpretasi struktural, Teluk Weda, pesisir dan pulau-pulau kecil

\begin{abstract}
Modeling in coastal area and small islands development of the Weda Bay in the central Halmahera regency aims to assess their management institutional forms using Interpretative Structural Modeling (ISM) method. Results of the study indicate that management institution required to ensure sustainable development of coastal area and small islands of the Weda Bay has to include : government, tourist and academic institution. An effort should be carried out to increase productivity, quality of fish product and financial capital of fishery investment through fish pricing policy, better fishery management local regulatory investment and conducive and consistens policies. Policies implication should be carried out by developing local regulations, disseminating laws and regulations, conducting training regarding the laws, maintaining local wisdom in resource management, and developing community group for site's establishment.
\end{abstract}

Keywords: Interpretative Structural Modeling (ISM), Weda Bay, coastal and small islands 


\section{PENDAHULUAN}

Menuju era industrialisasi, wilayah pesisir dan lautan termasuk prioritas utama untuk pusat pengembangan kegiatan industri, pariwisata, agribisnis, agroindustri, pemukiman, transportasi dan pelabuhan. Kondisi yang demikian menyebabkan banyak kota-kota yang terletak di wilayah pesisir terus dikembangkan dalam menyambut tata ekonomi baru dan kemajuan industrialisasi. Tidak mengherankan bila sekitar $65 \%$ penduduk Indonesia bermukim di sekitar wilayah pesisir dan pulau-pulau kecil (P3K) (Dahuri et al., 2001)

Sejumlah besar dari pulau-pulau yang membentuk kepulauan nusantara merupakan pulau-pulau berukuran kecil (lebih dari 10.000 pulau) yang tersebar dari sabang di ujung Barat hingga Merauke di ujung Timur. Walaupun hanya sebagian sebagian kecil saja dari pulau-pulau kecil tersebut yang berpenduduk, akan tetapi sulit untuk dikatakan bahwa pulau-pulau kecil yang tidak berpenduduk dan terpencil itu bebas dari pengeksploitasian atau bebas dari dampak kegiatan manusia (Dutton et al., 2001).

Pengembangan suatu wilayah pesisir dan pulau-pulau kecil memerlukan upaya pengelolaan yang sangat penting untuk memacu perkembangan sosial-ekonomi, mengurangi kesenjangan, dan menjaga kelestarian lingkungan hidup pada suatu wilayah, hal ini sangat diperlukan karena realitas sosial ekonomi, budaya dan geografis yang sangat berbeda antara suatu wilayah dengan wilayah lainnya. Dengan kata lain, pembangunan tidak dapat disamaratakan pada seluruh wilayah, akan tetapi harus disesuaikan dengan kondisi wilayah setempat. Inilah sesungguhnya yang merupakan argumentasi akan perlunya suatu pengembangan wilayah.

Logika di atas tentang pengembangan wilayah berbeda dengan pembangunan sektoral, karena yang pertama sangat berorientasi pada permasalahan (issues) pokok wilayah secara saling terkait, sementara yang disebutkan terakhir sesuai dengan tugasnya, bertujuan untuk mengembangkan sektor itu, tanpa terlalu memperhatikan keterkaitannya dengan sektorsektor lain. Namun demikian, walaupun berbeda dalam orientasi tapi keduanya saling melengkapi; dalam arti bahwa pengembangan wilayah tidak mungkin terwujud tanpa pembangunan sektoral, sementara pembangunan sektor tanpa berorientasi pada pengembangan wilayah akan berujung pada tidak optimalnya pembangunan sektor itu sendiri. Bahkan hal ini dapat menciptakan perselisihan (konflik) kepentingan antar sektor-sektor tersebut, yang pada gilirannya akan kontra-produktif dengan pengembangan wilayah.

Realitas menunjukkan bahwa Kabupaten Halmahera Tengah sebagai kabupaten yang memiliki teluk yang luas memiliki potensi sumberdaya dan jasa kelautan serta perikanan yang prospektif untuk mendukung proses pembangunan wilayah yang optimal. Dengan perkataan lain, dari sisi kemampuan memproduksi (supply capacity) barang dan jasa kelautan dan perikanan, sesungguhnya Kabupaten Halmahera Tengah memiliki potensi pembangunan yang masih besar dan terbuka lebar untuk berbagai pilihan pembangunan. Dengan demikian, penting untuk dipahami seberapa besar dukungan keberadaan teluk terhadap keberlangsungan sumberdaya kelautan secara umum.

Konsep pemanfaatan sumberdaya dan jasa-jasa kelautan serta perikanan di wilayah yang banyak memiliki ekosistem yang lengkap seperti di teluk Weda ini, maka hal yang tepat untuk dilakukan adalah pendekatan keterpaduan. Minimal keterpaduan ini dapat mengintegrasikan kegiatan perikanan dan wisata bahari yang dikembangkan pada wilayah berpotensi. Konsep kebijakan untuk menangani pesisir dan pulaupulau kecil merupakan suatu keharusan yang tidak bisa ditunda-tunda lagi. Lebih dari itu, program pemberdayaan pesisir dan pulau-pulau kecil yang mengarah pada ekspolitasi sumberdaya alam harus diubah menjadi pengelolaan dan pengembangan, yang tentu saja dalam hal ini melibatkan unsurunsur pemerintah, baik pemerintah pusat maupun pemerintah daerah yang bekerja sama dengan masyarakat lokal dan investor yang berwawasan lingkungan. Kolaborasi dari unsur-unsur ini lebih dikenal dengan model co-management. (Dahuri et al., 2001).

Salah satu teknik pemodelan co-management yang dikembangkan untuk perencanaan strategis pengembangan pesisir dan pulau-pulau kecil adalah Teknik Permodelan Interpretasi Struktural (Interpretatif Structural Modelling - ISM). ISM adalah proses pengkajian kelompok (group learning process) dimana model-model struktural dihasilkan guna memotret perihal yang kompleks dari suatu sistem, melalui pola yang dirancang seksama dengan menggunakan grafis serta kalimat 
(Eriyatno, 1998) Teknik ISM merupakan salah satu teknik permodelan sistem untuk menangani kebiasaan yang sulit diubah dari perencana jangka panjang yang sering menerapkan secara langsung teknik penelitian operasional dan atau aplikasi statistik deskriptif.

Lebih lanjut, Saxena etal. (1992) menjelaskan ISM bersangkut paut dengan interpretasi dari suatu obyek yang utuh atau perwakilan sistem melalui aplikasi teori grafis secara sistematis dan iteratif. ISM juga menganalisis eleman-elemen sistem dan memecahkanya dalam bentuk grafik dari hubungan langsung antar elemen dan tingkat hierarki. Elemen-elemen dapat merupakan tujuan kebijakan, target organisasi, faktor-faktor penilaian dan lainnya. Hubungan langsung dapat dalam konteks-konteks yang beragam (berkaitan dengan hubungan kontekstual). Tujuan penelitian ini adalah mengkaji bentuk kelembagaan bagi pengelolaan kawasan pesisir dan pulau-pulau kecil.

\section{METODOLOGI}

Analisis kelembagaan yang dilakukan menggunakan pengembangan model kelembagaan pengelolaan teluk dengan menggunakan metoda ISM yang dikembangkan oleh Saxena et al. (1992). Langkah-langkah ISM adalah sebagai berikut (Kanungo and Batnagar, 2002 dalam Eriyatno and Sofyar, 2007) terdiri dari :

(1) Identification of Element: elemen sistem diidentifikasi dan di daftar, (2) Contextual Relationship: sebuah hubungan kontekstual antara elemen dibangun tergantung pada tujuan dari pemodelan, (3) Structural Self Interaction Matrix (SSIM): matriks ini mewakili elemen persepsi responden terhadap elemen hubungan yang dituju, (4) Reachability Matrix (RM): Sebuah RM yang disiapkan kemudian mengubah simbol-simbol SSIM ke dalam sebuah matriks biner, (5) Level Partitioning: seluruh elemen sistem dikelompokkan ke dalam level-level yang berbeda, (6) Canonical Matrix: pengelompokkan elemen-elemen dalam level yang sama, (7) Digraph: konsep yang berasal dari Directional Graph yaitu sebuah grafik dari elemen-elemen yang saling berhubungan secara langsung dan level hierarki,dan (8) Interpretative Structural Model: ISM dibangkitkan dengan memindahkan seluruh jumlah elemen dengan deskripsi elemen aktual.

Matriks Interaksi Tunggal terstruktur Structural Self Interaction Matrix (SSIM) mewakili elemen persepsi responden terhadap elemen hubungan yang dituju. Empat simbol yang digunakan untuk mewakili tipe hubungan yang ada antara dua elemen dari sistem yang dipertimbangkan adalah : V, A, X dan $\mathrm{O}$.

$V=$ hubungan dari elemen $E_{i}$ terhadap $E_{j}$, tidak sebaliknya

$A=$ hubungan dari elemen $E_{j}$ terhadap $E_{i}$, tidak sebaliknya

$X=$ hubungan interrasi antara $E_{i}$ dan $E_{j}$, dapat sebaliknya

$\mathrm{O}=$ tidak ada hubungan antara $\mathrm{E}_{\mathrm{i}}$ dan $\mathrm{E}_{\mathrm{j}}$.

Adapun aturan-aturan konversi berikut menerapkan:. Adapun aturan-aturan konversi berikut menerapkan:

1) Jika hubungan $E_{i}$ terhadap $E_{j}=V$ dalam SSIM, maka elemen $\mathrm{E}_{\mathrm{ij}}=1$ dan $\mathrm{E}_{\mathrm{ji}}=0$ dalam $\mathrm{RM}$;

2) Jika hubungan $E_{i}$ terhadap $E_{j}=A$ dalam SSIM, maka elemen $\mathrm{E}_{\mathrm{ij}}=0$ dan $\mathrm{E}_{\mathrm{ji}}=1$ dalam $\mathrm{RM}$;

3) Jika hubungan $E_{i}$ terhadap $E_{j}=X$ dalam SSIM, maka elemen $\mathrm{E}_{\mathrm{ij}}=1$ dan $\mathrm{E}_{\mathrm{ji}}=1$ dalam $\mathrm{RM}$; dan

4) Jika hubungan $E_{i}$ terhadap $E_{j}=O$ dalam SSIM, maka elemen $\mathrm{E}_{\mathrm{ij}}=0$ dan $\mathrm{E}_{\mathrm{ji}}=0$ dalam $\mathrm{RM}$.

\section{Jenis dan Sumber Data}

Jenis data yang digunakan dalam penelitian ini adalah data sekunder yang diperoleh melalui penelusuran pustaka dan laporan berbagai instansi terkait pada Pemerintahan Kabupaten Halmahera tengah, sedangkan data primer diperoleh dari pengisian kuesioner dengan melakukan wawancara langsung terhadap stakeholders antara lain : pimpinan instansi, tokoh masyarakat, nelayan setempat, investor pariwisata, dan lain-lain.

\section{Metode Analisis Data}

Salah satu teknik pemodelan yang dikembangkan untuk perencanaan strategis adalah Teknik Permodelan Interpretasi Struktural (Interpretative Structural Modelling - ISM). Menurut Eriyatno (1998), ISM adalah proses pengkajian kelompok (group learning process) dimana modelmodel struktural dihasilkan guna memotret perihal yang kompleks dari suatu sistem, melalui pola yang dirancang seksama dengan menggunakan grafis serta kalimat. Teknik ISM merupakan salah satu teknik permodelan sistem untuk menangani kebiasaan yang sulit diubah dari perencana jangka panjang yang sering menerapkan secara langsung 
teknik penelitian operasional dan atau aplikasi statistik deskriptif.

Data yang diperoleh berdasarkan hasil wawancara dengan para stakeholders di lapangan, selanjutnya dilakukan analisis dengan menggunakan Interpretative Structural Model (ISM) yang pada dasarnya untuk menyusun hirarki setiap sub elemen pada elemen yang dikaji kemudian membuat klasifikasi ke dalam 4 (empat) sektor untuk menentukan sub elemen mana yang termasuk ke dalam variabel menurut Kholil (2005) dan Eriyatno (1998): autonomous (sektor 1), dependent (sektor 2), linkage (sektor 3), dan independent (sektor 4). Secara garis besar keempat variabel tersebut dapat dilihat pada Gambar 1.

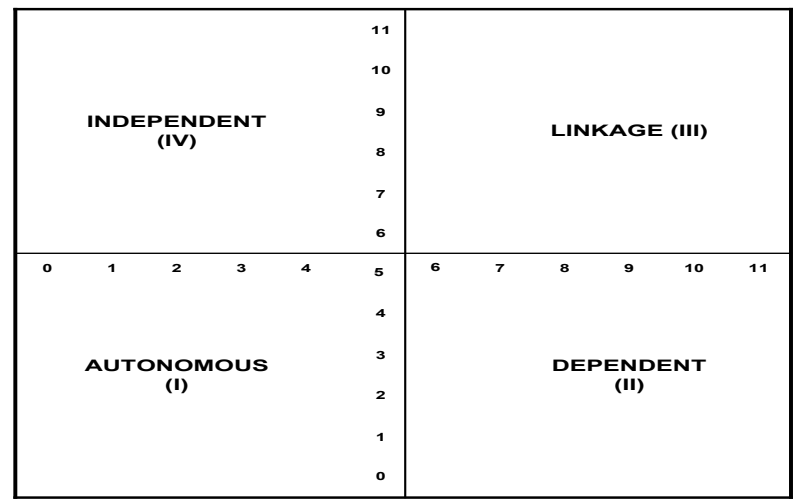

Gambar 1. Matriks DP-D untuk Elemen Tujuan Program.

Figure 1. DP-D Matrix of the Objective Program's Element.

Menurut Saxena et al. (1992) ISM bersangkut paut dengan interpretasi dari suatu obyek yang utuh atau perwakilan sistem melalui aplikasi teori grafis secara sistematis dan iteratif. ISM juga menganalisis eleman-elemen sistem dan memecahkannya dalam bentuk grafik dari hubungan langsung antar elemen dan tingkat hierarki. Elemen-elemen dapat merupakan tujuan kebijakan, target organisasi, faktor-faktor penilaian dan lainnya. Hubungan langsung dapat dalam konteks-konteks yang beragam (berkaitan dengan hubungan kontekstual).

Sistem kelembagaan Teluk Weda dapat diuraikan atas elemen-elemen yang terdiri dari (1) Elemen pelaku (masyarakat yang terpengaruh), (2) Elemen tujuan program, (3) Elemen tolok ukur untuk menilai setiap tujuan, (4) Elemen kendala utama, dan (5) Elemen aktivitas yang dibutuhkan guna perencanaan tindakan. Adapun pada penelitian ini dasar pertimbangan dalam pemilihan elemen dari program yang ingin dicapai adalah elemen dominan yang sudah dikonsultasikan dengan pakar dalam pengembangan kawasan konservasi pesisir dan pulau-pulau kecil di Teluk Weda.

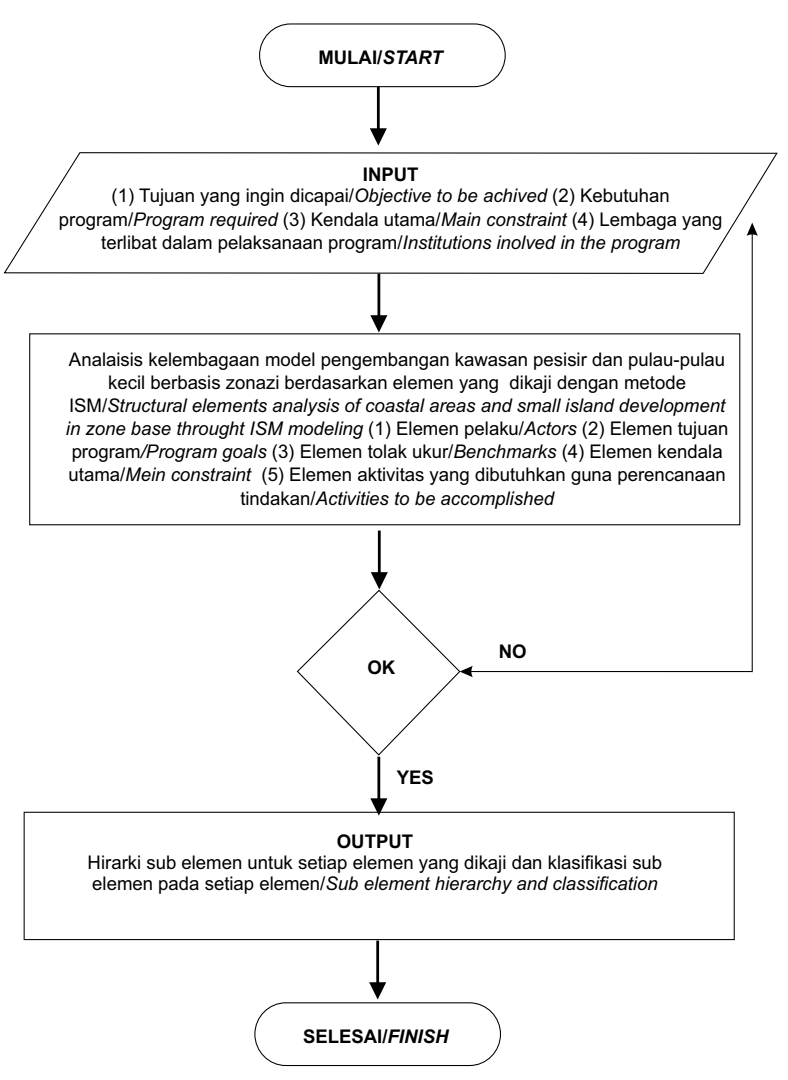

Gambar 2. Diagram Alir Analisis Kelembagaan dengan Metode ISM.

Figure 2. Institutional Analysis Flowchart of The ISM Method.

Sistem model pengembangan kawasan konservasi pesisir dan pulau-pulau kecil di Teluk Weda Kabupaten Halmahera Tengah dapat diuraikan atas 5 (lima) elemen. Perubahan masingmasing elemen sistem dalam upaya pengembangan pesisir dan pulau-pulau kecil di Teluk Weda terdiri dari sejumlah sub-elemen, meliputi:

Elemen Pelaku (masyarakat yang terpengaruh): Kebutuhan pelaku dalam model pengembangan kawasan konservasi pesisir dan pulau-pulau kecil dapat diartikan sebagai aktor-aktor yang terlibat dalam upaya mengembangkan pesisir dan pulau-pulau kecil.

Elemen Tujuan Program: Tujuan program dalam model pengembangan kawasan konservasi pesisir dan pulau-pulau kecil dapat diartikan untuk peningkatan berbagai elemen tujuan dalam upaya pengembangan pesisir dan 
pulau-pulau kecil.

Elemen Tolok Ukur: Elemen tolok ukur diperlukan dalam model pengembangan kawasan konservasi pesisir dan pulau-pulau kecil sebagai acuan akan keberhasilan dari tujuan.

Elemen Kendala Utama: Kendala utama dalam model pengembangan kawasan konservasi pesisir dan pulau-pulau kecil adalah bagian yang dapat menghambat pengembangan pesisir dan pulau-pulau kecil.

Elemen Aktivitas yang Dibutuhkan Guna Perencanaan Tindakan : Aktivitas yang dibutuhkan dalam model pengembangan kawasan konservasi pesisir dan pulau-pulau kecil adalah untuk perencanaan tindakan. Teknik analisis kelembagaan dengan metode ISM dapat dilihat pada Gambar 2.

\section{HASIL DAN PEMBAHASAN}

Hasil penilaian pakar terhadap hubungan kontekstual antar sub-elemen menghasilkan matriks SSIM (Self Structural Interpretative Matrix) dan hasil penilaian tersebut dikonversi menjadi matriks reachability (RM) awal. Matriks reachability yang belum $\mathrm{m}$ emenuhi aturan transitivity, kemudian dilakukan konversi menjadi matriks reachability yang memenuhi aturan transitivity, sehingga diperoleh matriks reachability akhir. Selanjutnya dibentuk SSIM akhir yang memenuhi aturan transitivity. SSIM akhir yang memenuhi aturan transitivity dinterpretasikan dalam kelembagaan, kemudian disajikan dalam diagram model struktur hirarki elemen sistem pengembangan kawasan pesisir dan pulau-pulau kecil di Teluk Weda.

Strukturisasi sub-elemen Sistem Pengembangan Kawasan Pesisir dan Pulau-Pulau Kecil antara lain :

\section{a. Elemen Pelaku Sistem Pengembangan}

Strukturisasi elemen pelaku, yang terdiri dari 10 sub-elemen, dengan menggunakan teknik ISM dan melalui penilaian $\mathrm{V}, \mathrm{A}, \mathrm{X}$, dan $\mathrm{O}$ akan menghasilkan matriks reachability, struktur model hirarki, dan klasifikasi sub elemen. Sub elemen pelaku dilambangkan sebagai berikut:

1. Kelompok Nelayan (L1)

2. Pengusaha industri perikanan (L2)

3. Tokoh masyarakat (L3)

4. Pemerintah daerah (L4)
5. Pemerintah pusat (L5)

6. Wisatawan dalam negeri (L6)

7. Wisatawan luar negeri (L7)

8. Lembaga keuangan dan Bank (L8)

9. Investor wisata bahari (L9)

10. Investor wisata bahari (L10)

Pada diagram dan grafik yang ditampilkan pada Gambar 3 dan 4, menjelaskan bahwa elemen pelaku sistem pengembangan kawasan konservasi pesisir dan pulau-pulau kecil pada level I adalah pemerintah pusat, wisatawan dalam negeri dan perguruan tinggi, level II adalah tokoh masyarakat dan wisatawan luar negeri, level III adalah kelompok nelayan, level IV adalah pengusaha industri perikanan dan lembaga keuangan dan bank, dan level $\mathrm{V}$ adalah pemerintah daerah dan investor pariwisata bahari.

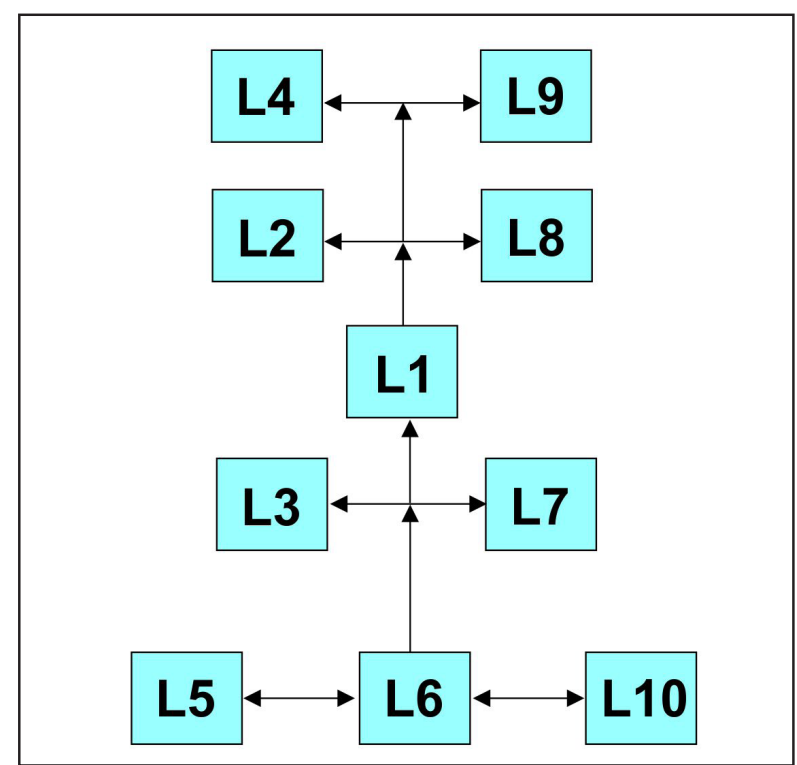

Gambar 3. Diagram Model Struktur Hirarki Elemen Pelaku.

Figure 3. Model Hierarchy Structure Actors Elements Diagram.

Kawasan Teluk Weda merupakan kawasan yang dalam pengelolaan dan pemanfaatan membutuhkan keterpaduan (integration), terkait dengan beragamnya ekosistem dan pemanfaatan yang dilakukan. Kondisi tersebut menjadikan pengelolaan berupa pengembangan kawasan di Teluk Weda merupakan kegiatan yang mengelaborasi sejumlah kepentingan. Dalam kaitannya dengan pengelolaan sumber daya alam, pengelolaan dapat dipahami sebagai hak untuk mengatur pola penggunaan internal dan mengubah sumber daya dengan membuat perbaikan (Ostrom 
\& Schlager, 1996). Kegiatan pengelolaan ini dapat ditampilkan oleh satu stakeholder atau bersama-sama oleh kelompok atau sebagai hasil kerjasama antara berbagai kelompok. Manajemen kolaboratif, atau co-manajemen, telah didefinisikan sebagai pembagian kekuasaan dan tanggung jawab pengguna sumberdaya antara pemerintah dan lokal (Berkes et al., 1991). Singleton (1998) mendefinisikan co-manajemen sebagai istilah yang diberikan kepada sistem yang menggabungkan pemerintahan sebagai kontrol dengan lokal, pengambilan keputusan yang terdesentralisasi dan akuntabilitas, idealnya dengan menggabungkan kekuatan dan mengurangi kelemahan masingmasing.

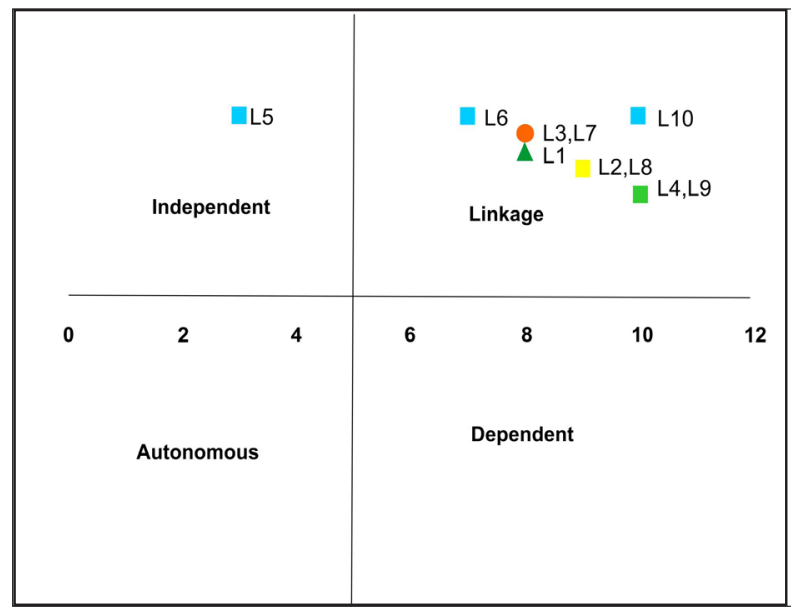

Gambar 4. Grafik Hubungan Driver Power (DP) dan Dependence (D) Elemen Pelaku.

Figure 4. Relationship Graph Driver Power (DP) and Dependence (D) Actors Elements.

Mengacu pada hal tersebut, dalam perencanaan kawasan di Teluk Weda, sebagai bentuk bentuk mendesentralisasikan tanggung jawab dan wewenang dalam pengelolaan sumberdaya, diperlukan pelibatan segenap stakeholder terkait dari pemerintah daerah, investor pariwisata bahari, pengusaha industri perikanan, lembaga keuangan dan bank, kelompok nelayan, tokoh masyarakat, wisatawan luar negeri, pemerintah pusat, wisatawan dalam negeri dan perguruan tinggi. Desentralisasi tanggung jawab dapat menjadikan keberlangsungan segenap ekosistem yang ada di Teluk Weda lebih terjamin dengan keterlibatan stakeholder terkait baik sebagai pengguna sekaligus pengawas. Stakeholder dalam kapasitasnya sebagai pengguna (users) akan berusaha dalam pemanfaatan sumberdaya tetap memperhatikan kaidah-kaidah dan mentaati segenap aturan yang telah ditetapkan secara bersama pada proses perencanaan, sekaligus mengawasi terjadinya bentuk pemanfaatan yang merugikan. Lebih lanjut pelaksanaan co-management tidak hanya terkait dengan pembagian tanggung jawab pengelolaan, tetapi juga mensyaratkan adanya kerjasama, partisipasi, peningkatan pengetahuan lokal, dan penggunaan pengetahuan ekologi tradisional dan pengetahuan ilmiah (IwasakiGoodman, 2005).

\section{b. Elemen Tujuan Program Pengembangan}

Strukturisasi elemen Tujuan yang terdiri dari 12 sub elemen, dengan menggunakan teknik ISM dan melalui penilaian $\mathrm{V}, \mathrm{A}, \mathrm{X}$, dan $\mathrm{O}$ akan menghasilkan matriks reachability, struktur model hirarki, dan klasifikasi sub-elemen. Sub-elemen tujuan dilambangkan sebagai berikut :

1. Mewujudkan pengembangan wisata (T1)

2. Meningkatkan produktivitas perikanan tangkap (T2)

3. Meningkatkan kualitas hidup masyarakat pesisir dan pulau-pulau kecil (T3)

4. Meningkatkan pelayanan jasa lingkungan di pesisir dan pulau-pulau kecil (T4)

5. Meningkatkan pendapatan masyarakat pesisir dan pulau-pulau kecil (T5)

6. Mewujudkan pemanfaatan umberdaya yang berkelanjutan (T6)

7. Memperluas lapangan kerja (T7)

8. Meningkatkan diversifikasi produk perikanan tangkap (T8)

9. Meningkatkan kegiatan perekonomian daerah pesisir dan pulau-pulau kecil (T9)

10. Meningkatkan minat investor kepariwisataan (T10)

11. Melakukan pengembangan teknologi (T11)

12. Meningkatkan pendapatan daerah (T12)

Pada diagram dan grafik yang ditampilkan pada Gambar 5 dan 6, menjelaskan bahwa elemen tujuan program sistem pengembangan kawasan konservasi pesisir dan pulau-pulau kecil pada level I adalah mewujudkan pengembangan wisata, level II adalah meningkatkan produktivitas perikanan tangkap, meningkatkan kualitas hidup masyarakat pesisir dan pulau-pulau kecil, meningkatkan pelayanan jasa lingkungan di pesisir dan pulaupulau kecil dan melakukan pengembangan teknologi, level III adalah meningkatkan diversifikasi 
produk perikanan tangkap dan meningkatkan minat investor kepariwisataan, level IV adalah mewujudkan pemanfaatan SD yang berkelanjutan, level $\mathrm{V}$ adalah meningkatkan pendapatan masyarakat pesisir dan pulau-pulau kecil, level VI adalah memperluas lapangan kerja, level VII adalah meningkatkan kegiatan perekonomian daerah pesisir dan pulau-pulau kecil, sedangkan level VIII adalah meningkatkan pendapatan daerah.

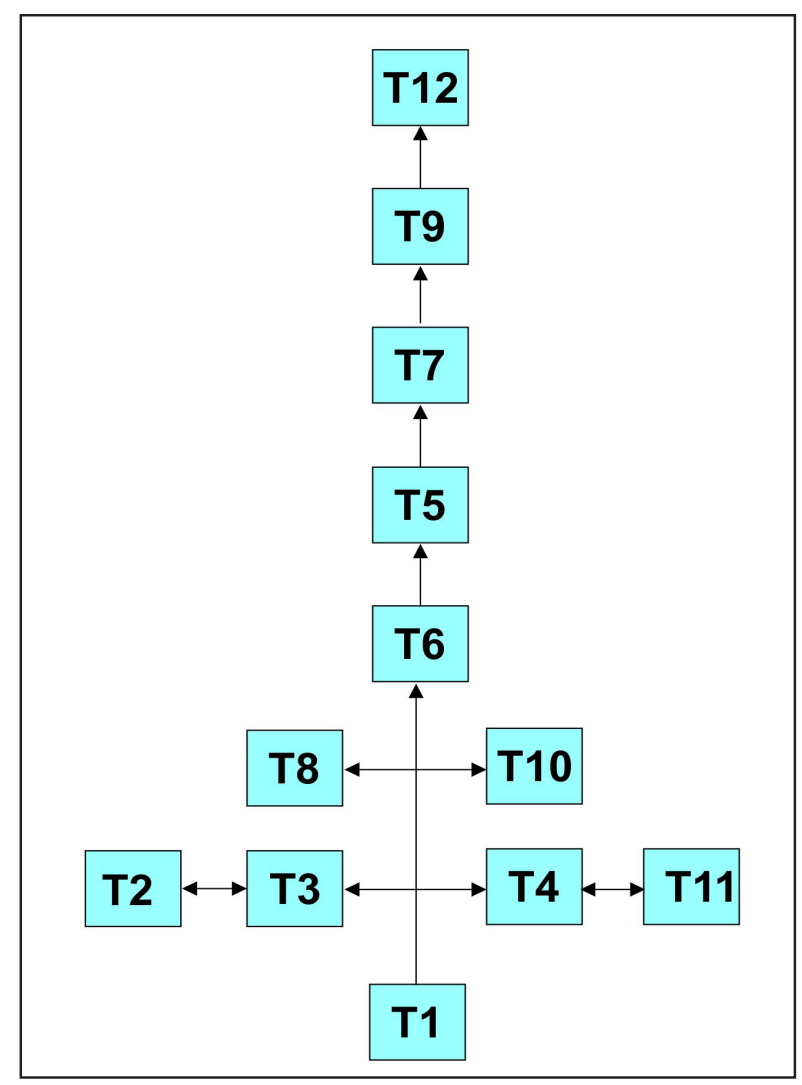

Gambar 5. Diagram Model Struktur Hirarki Elemen Tujuan Program.

Figure 5. Model Hierarchy Structure Element Program Target Diagram.

Berdasarkan hirarki di atas menunjukkan bahwa tujuan program dalam mewujudkan pengembangan wisata memegang peranan penting pada pengembangan kawasan pesisir dan pulaupulau kecil di Teluk Weda.

Pengembangan kawasan pesisir dan pulau-pulau kecil merupakan sebuah daerah yang dapat dijadikan kawasan konservasi terutama didedikasikan untuk perlindungan dan pemeliharaan keanekaragaman hayati, sumberdaya alam dan budaya yang diasosiasikan, atau dikelola melalui upaya hukum (Olsen, 2002). Dalam jangka panjang, pelaksanaan
Co-management pada kawasan pesisir dan pulau-pulau kecil diyakini akan memberikan perubahan-perubahan ke arah yang lebih baik melalui: 1) Peningkatan kesadaran masyarakat akan pentingnya sumberdaya pesisir dan laut dalam menunjang kehidupan; 2) Peningkatan kemampuan masyarakat, sehingga mampu berperan serta dalam setiap tahapan pengelolaan secara terpadu; dan 3) Peningkatan pendapatan masyarakat dengan bentuk-bentuk pemanfaatan yang lestari dan berkelanjutan serta berwawasan lingkungan Terkait dengan hal tersebut diperlukan perbaikan yang mendasar di dalam perencanaan dan pengelolaan pembangunan sumberdaya alam pesisir dan pulau-pulau kecil. Pola pembangunan yang hanya berorientasi pada pertumbuhan ekonomi perlu diganti dengan pembangunan berkelanjutan. Pendekatan dan praktek pengelolaan pembangunan wilayah pesisir yang selama ini dilaksanakan secara sektoral dan terpilah-pilah, perlu diperbaiki melalui pendekatan pengelolaan secara terpadu dan berkelanjutan.

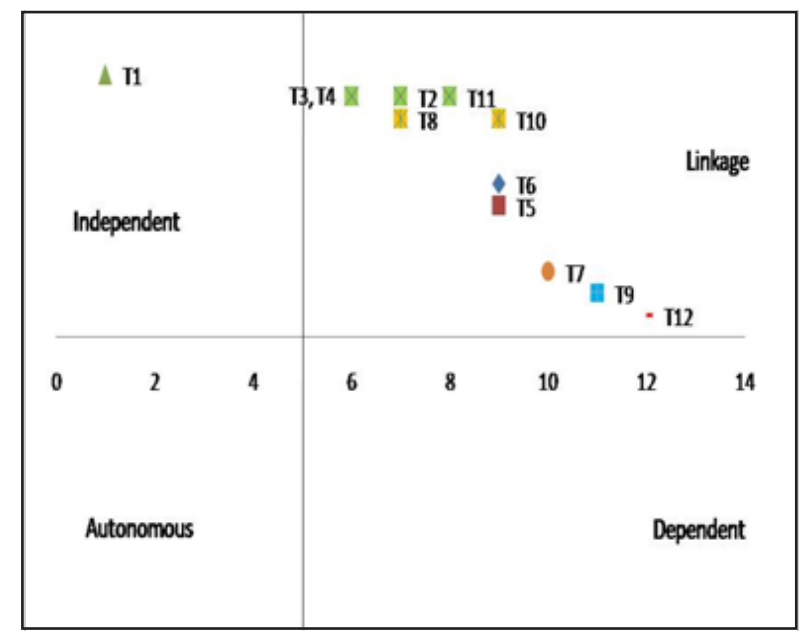

Gambar 6. Grafik Hubungan Driver Power (Dp) dan Dependence (D) Elemen Tujuan Program.

Figure 6. Relationship Graph of Driver Power (DP) and Dependence (D) Elements Program Target.

Setiap perencanaan dan pengelolaan sumberdaya pesisir dan pulau-pulau kecil perlu mempertimbangkan beberapa pertimbangan yaitu ekonomi, lingkungan dan sosial budaya (Supriharyono, 2000). Perilaku masyarakat dalam mengelola pesisir dan pulau-pulau kecil di TelukWeda masih secara tradisional yaitu dengan penggunaan teknologi penangkapan dan pengolahan hasil 
perikanan yang sederhana. disamping itu dinamika sosial budaya masyarakat pesisir dan pulau-pulau kecil seperti, kepemimpinan informal, keragaan nelayan, kualitas program pemberdayaan, kompetensi fasilitator, dan kualitas pendukung memiliki pengaruh positif langsung terhadap perilaku nelayan. Serta pemberdayaan masyarakat berpengaruh positif yang nyata terhadap perilaku nelayan dalam meningkatkan kesejahteraan. Pengembangan masyarakat pesisir mengarah pada meningkatnya kualitas hidup nelayan dan keluarganya melalui pengelolaan secara terpadu dengan mengakomodasi kepentingan ekologis, sosial budaya, dan ekonomi yang ditekankan pada mekanisme kerja sistem penyuluhan, sistem sosial, dan sistem lingkungan antara pemerintah, swasta, dan pihak terkait diperlukan guna mengembangkan masyarakat pesisir yang mampu memelihara kondisi pengelolaan bagi kesejahteraan (Amanah Islamic Bank Rules and Regulations, 2006).

\section{c. Elemen Tolok Ukur Sistem Pengembangan}

Strukturisasi elemen tolok ukur, yang terdiri dari 10 subelemen, dengan menggunakan teknik ISM dan melalui penilaian $\mathrm{V}, \mathrm{A}, \mathrm{X}$, dan $\mathrm{O}$ akan menghasilkan matriks reachability, struktur model hirarki, dan klasifikasi subelemen. Sub elemen tolok ukur dilambangkan sebagai berikut:

1. Meningkatnya industri pariwisata (U1)

2. Meningkatnya jumlah hasil tangkapan (U2)

3. Meningkatnya taraf hidup masyarakat pesisir dan pulau-pulau kecil (U3)

4. Meningkatnya produktifitas pemanfaatan sumberdaya alam (U4)

5. Meningkatnya mutu produk perikanan (U5)

6. Meningkatnya pendapatan masyarakat pesisir dan pulau-pulau kecil (U6)

7. Meningkatnya jumlah investor dan investasi di pesisir dan pulau-pulau kecil (U7)

8. Meningkatnya diversifikasi produk perikanan (U8)

9. Meningkatnya jumlah permodalan kegiatan perikanan tangkap (U9)

10. Harga produk perikanan yang stabil (U10)

Pada diagram dam grafik yang ditampilkan pada Gambar 7 dan 8, menjelaskan bahwa elemen tolok ukur program sistem pengembangan kawasan konservasi pesisir dan pulaupulau kecil pada level I adalah meningkatnya industri pariwisata, meningkatnya produktifitas pemanfaatan sumberdaya alam, meningkatnya mutu produk perikanan, dan meningkatnya jumlah permodalan kegiatan perikanan tangkap, level II adalah meningkatnya diversifikasi produk perikanan dan harga produk perikanan yang stabil, level III adalah meningkatnya jumlah investor dan investasi di pesisir dan pulau-pulau kecil, level IV adalah meningkatnya jumlah hasil tangkapan, sedangkan level $\mathrm{V}$ adalah meningkatnya taraf hidup masyarakat pesisir dan pulau-pulau kecil.

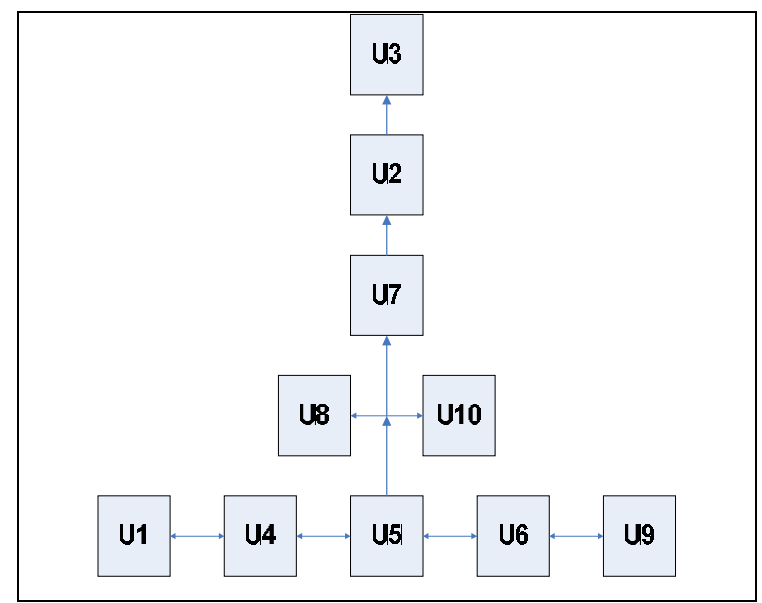

Gambar 7. Diagram Model Struktur Hirarki Elemen Tolok Ukur.

Figure 7. Model Hierarchy Structure Elements Indicator Diagram.

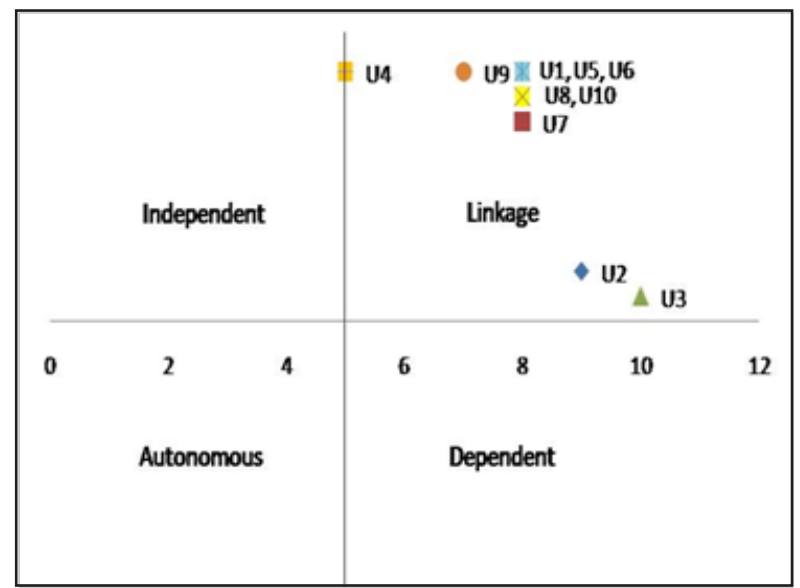

Gambar 8. Grafik Hubungan Driver Power (DP) dan Dependence (D) Elemen Tolok Ukur.

Figure 8. Relationship Graph of Driver Power (DP) and Dependence (D) Elements Indicator.

Wilayah pesisir dan pulau-pulau kecil memberikan manfaat yang cukup besar bagi masyarakat, sementara pada saat yang sama aktivitas manusia mengerahkan tekanan pada 
ekosistem pesisir dan pulau-pulau kecil, sehingga mengancam manfaat yang sama (Nobre, 2009). Untuk mempromosikan penggunaan berkelanjutan sumberdaya wilayah pesisir dan pulau-pulau kecil pendekatan ekosistem adalah nilai yang cukup besar, pertama dalam memahami hubungan kausal antara sistem lingkungan dan sosialekonomi, dan dampak kumulatif dari berbagai kegiatan yang dikembangkan dalam ekosistem pesisir (Nobre dan Ferreira, 2009), kedua untuk mengelola sumber daya pesisir dan pulau-pulau kecil serta keanekaragaman hayati (Browman \& Stergiou, 2005; Murawski, 2007). Co-management adalah konsensus ilmiah muncul melengkapi Integrated Coastal Zone Management (ICZM). Co-Management juga menyoroti kebutuhan penggunaan pengetahuan terbaik yang tersedia tentang ekosistem untuk mengelola sumberdaya kelautan, dengan penekanan pada fungsi ekosistem menjaga layanan (Murawski, 2007)

Teluk Weda merupakan sebuah kawasan yang terdiri dari sejumlah ekosistem memiliki potensi perikanan yang besar. Kondisi ini menyebabkan sebagian besar masyarakat menggantungkan hidup pada sumberdaya perikanan ini. Terkait dengan perencanaan kawasan konservasi dengan salah satu tujuannya adalah peningkatan pendapan, tolak ukur yang relevan untuk digunakan berupa peningkatan produksi perikanan. Peningkatan produksi perikanan ini tidak semata-mata berupa peningkatan hasil tangkap tapi diutamakan berupa diversifikasi produk perikanan.

Diversifikasi produk perikanan merupakan salah satu strategi dalam mengkomersilkan sektor perikanan di Teluk Weda. Diversifikasi selain lebih memberikan pilihan produk juga akan mmberikan nilai tambah bagi masyarakat. Nilai tambah yang dimaksud berupa adanya kegiatan supplementer bagi kegiatan perikanan seperti, pengemasan dan pemasaran sehingga menambah rantai suplai (supply chain) dalam pemanfaatan sumerdaya perikanan di Teluk Weda.

\section{d. Elemen Kendala Utama Sistem Pengembangan}

Strukturisasi elemen kendala utama, yang terdiri dari 10 sub elemen, dengan menggunakan teknik ISM dan melalui penilaian V, A, X, dan O akan menghasilkan matriks reachability, struktur model hirarki, dan klasifikasi subelemen. Sub elemen kendala dilambangkan sebagai berikut :

1. Nelayan kurang berdaya dalam penentuan harga perikanan (K1)
2. Nelayan kurang konsisten menjaga mutu perikanan tangkap (K2)

3. Lemahnya nelayan dapat mengakses modal pada lembaga keuangan dan bank (K3)

4. Lemahnya kemampuan masyarakat dalam mengelola sumberdaya alam pesisir dan pulau- pulau kecil (K4)

5. Kurangnya pembinaan terhadap nelayan (K5)

6. Lemahnya sistem kelembagaan di pesisir dan pulau-pulau kecil (K6)

7. Lemahnya koordinasi antar pihak terkat (K7)

8. Tingginya kebutuhan ekspor perikanan tangkap (K8)

9. Peraturan investasi daerah yang kurang mendukung (K9)

10. Kebijakan pemerintah yang tidak konsisten (K10)

Pada diagram dam grafik yang ditampilkan pada Gambar 9 dan 10, menjelaskan bahwa elemen kendala program sistem pengembangan kawasan konservasi pesisir dan pulau-pulau kecil pada level I adalah nelayan kurang berdaya dalam penentuan harga perikanan, lemahnya kemampuan masyarakat dalam mengelola sumberdaya alam pesisir dan pulau-pulau kecil, peraturan investasi daerah yang kurang mendukung dan kebijakan pemerintah yang tidak konsisten, level II adalah nelayan kurang konsisten menjaga mutu perikanan tangkap, level III adalah tingginya kebutuhan ekspor perikanan tangkap, level IV adalah lemahnya nelayan dapat mengakses modal pada lembaga keuangan dan bank dan lemahnya sistem kelembagaan di pesisir dan pulau-pulau kecil, level $\mathrm{V}$ adalah lemahnya koordinasi antar pihak terkait, dan level VI adalah konsistenkurangnya pembinaan terhadap nelayan.

Perencanaan pengembangan kawasan pesisir dan pulau-pulau kecil di Teluk Weda diharapkan memberikan manfaat terbesar bagi masyarakat khususnya nelayan sesuai dengan kapasitas ekonomi yang sesuai dengan daya dukung serta kebijakan sosial ekonomi yang berpihak kepada kelompok yang terpinggirkan. Kebijakan sosial ekonomi perlu direkayasaulang, yakni diarahkan untuk kesejahteraan masyarakat khususnya nelayan sekaligus untuk menjaga kelestarian sumberdaya sehingga kegiatan sosial ekonomi dapat dipercepat dan dilakukan secara berkelanjutan. 


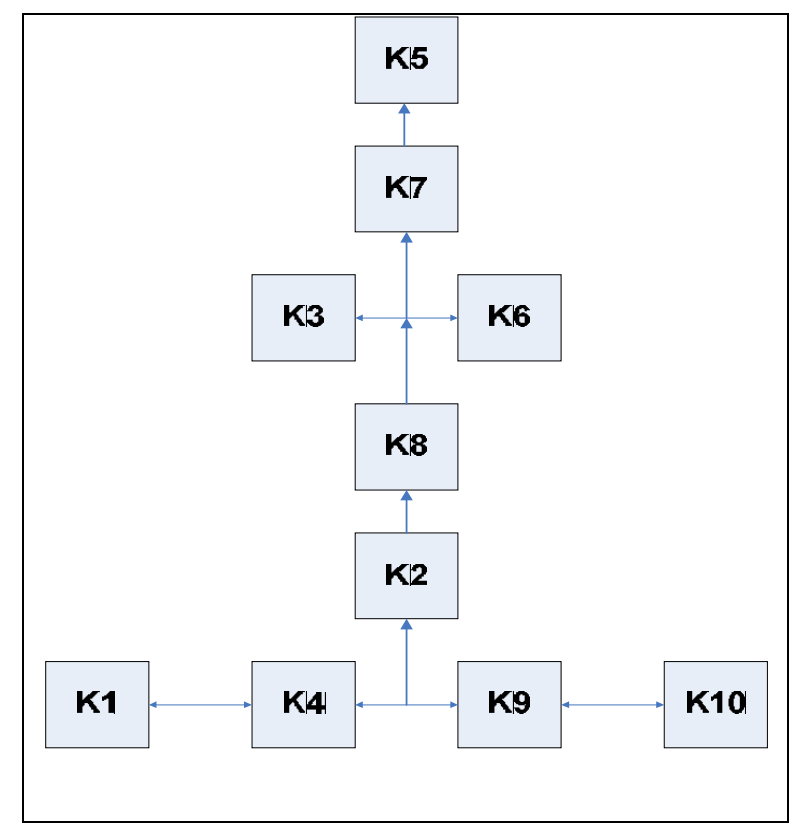

Gambar 9. Diagram Model Struktur Hirarki Elemen Kendala Utama.

Figure 9. Model Hierarchy Structure Elements Main Constraints Diagram.

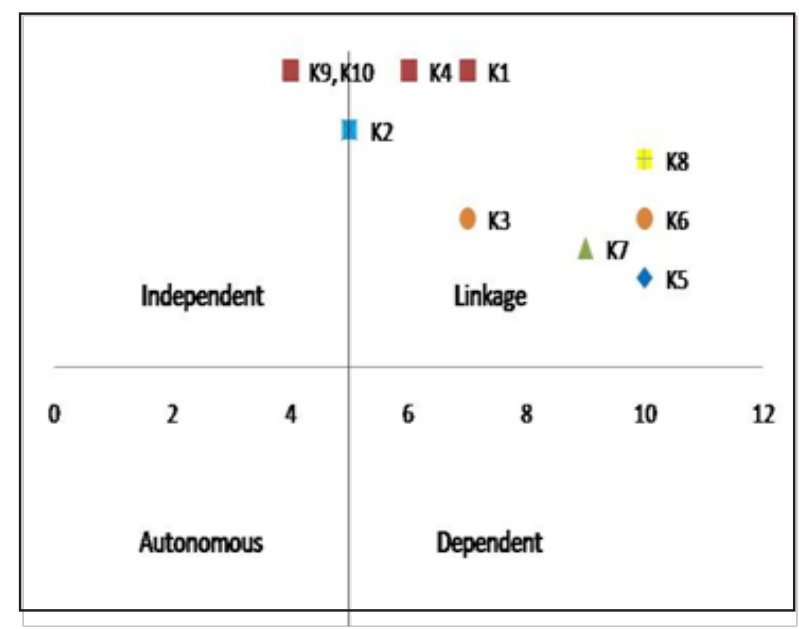

Gambar 10. Grafik Hubungan Driver Power (DP) dan Dependence (D) Elemen Kendala Utama.

Figure 10. Relationship Graph of Driver Power (DP) and Dependence (D) Elements Main Constraints.

Pengembangan masyarakat pesisir dan pulau-pulau harus didasarkan pada pengelolaan wilayah pesisir dan lautan yang komperehensif, sehingga menuntut (1) perhatian yang lebih mendalam dan menyeluruh mengenai sumberdaya alam yang unik; (2) optimalisasi pemanfaatan serbaneka dari ekosistem pesisir dan laut dengan mengitegrasikan segenap informasi ekologis, ekonomis dan sosial; dan (3) peningkatan pendekatan multidisipliner dan koordinasi antar sektoral dalam mengatasi permasalahan yang ada di wilayah pesisir dan pulau-pulau kecil yang kompleks. Melalui pendekatan ini, diharapkan dapat memberikan hasil yang diharapkan, yaitu (1) terpeliharanya kualitas lingkungan pesisir dan pulau-pulau kecil beserta sumberdaya didalamnya, dan (2) membaiknya kondisi sosial ekonomi-budaya masyarakat pesisir dan pulau-pulau kecil. Kebijakan pembangunan perlu memberikan keberpihakan kepada masyarakat pesisir dan pulau-pulau kecil agar kelompok masyarakat yang selama ini kurang diperhatikan dapat segera mengejar ketertinggalan dari kelompok masyarakat lainnnya sehingga tujuan pembangunan untuk mencapai kesejahteraan yang adil bagi segenap bangsa Indonesia dapat diwujudkan (Cincin-Sain \& Knecht 1998).

Lebih lanjut Dahuri et al. (2001) menjelaskan upaya pembinaan nelayan untuk pembangunan nasional dapat dilakukan melalui program: a) pembinaan nelayan memerlukan pemahaman yang bersifat menyeluruh terhadap setiap persoalan, terutama kemiskinan nelayan yang terjadi; b) pembinaan nelayan memerlukan pendekatan social engineering yang tepat, efektif dan efisien; c) penetapan jumlah pemanfaat (users) dan daya dukung lingkungannya sesuai dengan karakteristik sumberdaya dan pemanfaatannya; d) penguatan dan pembinaan masyarakat pesisir dan pulaupulau kecil; e) pengembangan mata pencaharian alternatif; f) penanganan penangkapan ikan ilegal, tidak tercatat dan tidak diatur; g) dukungan kebijakan pengembangan perikanan tangkap; dan h) dukungan kebijakan pengembangan perikanan budidaya.

\section{e. Elemen Kebutuhan Aktivitas Dalam Pengembangan}

Strukturisasi elemen aktivitas yang dibutuhkan, yang terdiri dari 10 sub elemen, dengan menggunakan teknik ISM dan melalui penilaian $\mathrm{V}, \mathrm{A}, \mathrm{X}$, dan $\mathrm{O}$ akan menghasilkan matriks reachability, struktur model hirarki, dan klasifikasi sub elemen. Sub elemen aktivitas yang dibutuhkan dilambangkan sebagai berikut :

1. Membuat kebijakan yang konsisten (A1)

2. Memfasilitasi pelaksanaan pendidikan (A2)

3. Memfasilitasi akses modal pengembangan (A3) 
4. Memfasilitasi penelitian dan pengembangan bekerjasama dengan perguruan tinggi (A4)

5. Memfasilitasi tersedianya infrastruktur yang memadahi (A5)

6. Memberikan pengawasan pemanfaatan sumberdaya alam (A6)

7. Melaksanakan promosi keaneka-ragaman hayati pesisir dan pulau-pulau kecil (A7)

8. Mendirikan sarana pelayanan (A8)

9. Melakukan koordinasi antar instansi terkait (A9)

10. Memfasilitasi penyediaan data dan informasi (A10)

Pada diagram dan grafik yang ditampilkan pada Gambar 11 dan 12, menjelaskan bahwa elemen aktivitasyang dibutuhkan guna perencanaan tindakan program sistem pengembangan kawasan konservasi pesisir dan pulau-pulau kecil pada level I adalah membuat kebijakan yang konsisten, level II adalah memfasilitasi pelaksanaan pendidikan, memfasilitasi penelitian dan pengembangan bekerjasama dengan perguruan tinggi, memfasilitasi tersedianya infrastruktur yang memadahi, memberikan pengawasan pemanfaatan sumberdaya alam dan melakukan koordinasi antar instansi terkait, sedangkan level III adalah memfasilitasi akses modal pengembangan, melaksanakan promosi keanekaragaman hayati pesisir dan pulau-pulau kecil, mendirikan sarana pelayanan dan memfasilitasi penyediaan data dan informasi.

Selama ini pengelolaan sumberdaya sering merupakan the missing ingredient dalam mewujudkan partisipasi masyarakat yang aktif dan kreatif. Secara sederhana pemberdayaan mengacu kepada kemampuan masyarakat untuk mendapatkan dan memanfaatkan akses dan kontrol atas sumber-sumber hidup yang penting. Upaya masyarakat untuk melibatkan diri dalam proses pembangunan melalui power yang dimilikinya merupakan bagian dari pembangunan manusia (personal/human development). Pembangunan manusia merupakan proses pembentukan pengakuan diri (self-respect), percaya diri (selfconfident) dan kemandirian (self-reliance) dapat bekerja sama dan toleran terhadap sesamanya dengan menyadari potensi yang dimilikinya. Hal ini dapat terwujud dengan menimba ilmu dan keterampilan baru, serta aktif berpartisipasi dalam pembangunan ekonomi, sosial dan politik serta komunitas mereka (Hanson, 2003; Kennish, 2002).
Terkait dengan hal tersebut tersedianya infrastruktur yang memadai, akan mengurangi missing ingredient dalam pengelolaan kawasan pesisir dan pulau-pulau kecil di Teluk Weda. Melalui penyediaan infrastruktur yang memadai, setiap stakeholder yang terlibat memiliki kesempatan untuk menyampaikan aspirasi, merumuskan solusi permasalahan yang ada sekaligus menggagas kegiatan yang diperlukan dalam mengelola kawasan Teluk Weda.

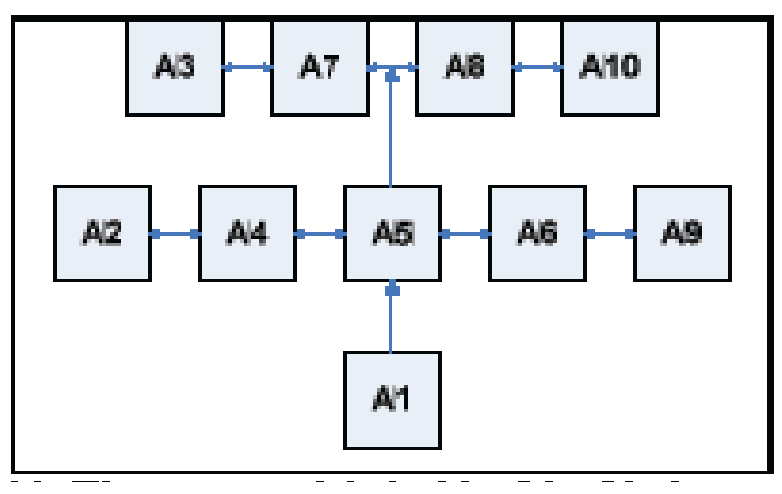

Gambar 11. Diagram Model Struktur Hirarki Elemen Aktivitas.

Figure 11. Model Hierarchy Structure Elements Activity Diagram.

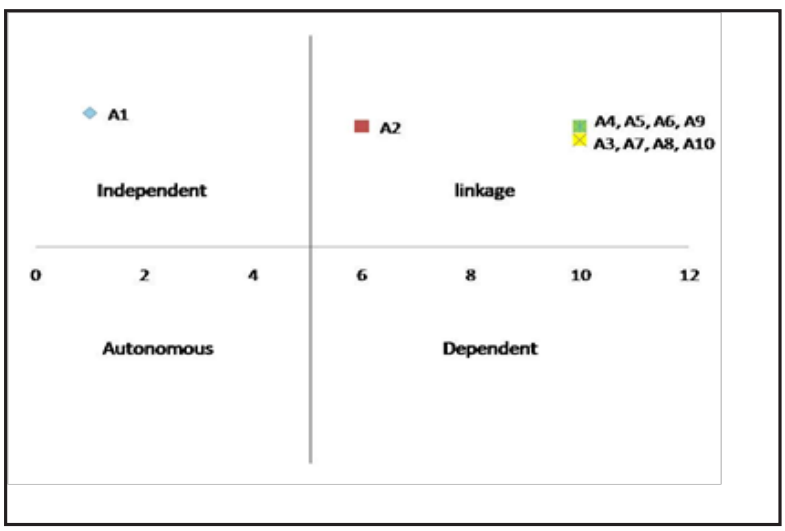

Gambar 12. Grafik hubungan Driver Power (DP) dan Dependence (D) Elemen Aktivitas.

Figure 12. Relationship Graph Driver Power (DP) and Dependence (D) Elements Activity.

\section{Kebijakan Pengembangan Kelembagaan}

Sistem kelembagaan dibutuhkan untuk mengatur kawasan konservasi untuk pengelolaan dan keberlanjutan sumberdaya pesisir dan pulaupulau kecil. Elemen pelaku sistem pengembangan kawasan konservasi pesisir dan pulau-pulau kecil yang diharapkan dalam menyelenggarakan adalah 
pemerintah pusat, wisatawan dalam negeri dan perguruan tinggi.

Pemerintah pusat diharapkan dapat memperkenalkan kawasan konservasi di Teluk Weda dengan cara melakukan promosi secara regional maupun internasional lewat lembaga yang berwenang di bidang pariwisata. Wisatawan dalam negeri diharapkan lebih mengenal dan berkunjung ke lokasi wisata yang ada di Teluk Weda, juga dapat dilakukan dengan cara memperkenalkan lokasi tersebut kepada calon wisatawan yang lain yang belum pernah berkunjung ke daerah tersebut.

Perguruan tinggi diharapkan dapatmelakukan penelitian pada zona inti agar dapat diketahui seberapa besar zona tersebut dapat direhabilitasi jika telah terjadi kerusakan, sedangkan yang masih baik dapat dipertahankan ekosistemnya. Pada zona pemanfaatan terbatas diharapkan perguruan tinggi dapat membantu memberikan pelatihan kepada masyarakat setempat dalam hal pengelolaan kawasan tersebut dengan pelatihan penyelaman yang baik yang tidak merusak ekosistem karang dan lingkungannya, untuk kawasan mangrove dilakukan penanaman kembali mangrove yang sudah terdegradasi bekerjasama dengan Dinas Kehutanan, Dinas Perikanan dan masyarakat yang terdapat di Kabupaten Halmahera Tengah. Pengelolaan zona perikanan berkelanjutan diharapkan perguruan tinggi dapat melakukan kajian yang berkaitan dengan keramba jaring apung dan budidaya rumput laut, sehingga nelayan yang melakukan usaha budidaya tersebut dapat meningkatkan pendapatannya dan keahliannya dalam pengembangan kegiatan budidaya tersebut.

Elemen pelaku sistem dapat melakukan manajemen kolaboratif, atau co-manajemen, yang didefinisikan sebagai pembagian kekuasaan dan tanggung jawab pengguna sumberdaya antara pemerintah dan lokal sebagai istilah yang diberikan kepada sistem yang menggabungkan pemerintahan sebagai kontrol dengan lokal, pengambilan keputusan yang terdesentralisasi dan akuntabilitas, idealnya dengan menggabungkan kekuatan dan mengurangi kelemahan masing-masing.

Salah satu elemen tujuan program pengembangan kawasan konservasi pesisir dan pulau-pulau kecil adalah mewujudkan pengembangan wisata. Pengembangan kawasan pesisir dan pulau-pulau kecil merupakan sebuah daerah yang dapat dijadikan kawasan konservasi terutama didedikasikan untuk perlindungan dan pemeliharaan keanekaragaman hayati, sumber daya alam dan budaya yang diasosiasikan atau dikelola melalui upaya hukum. Setiap perencanaan dan pengelolaan sumberdaya pesisir dan pulaupulau kecil perlu mempertimbangkan beberapa pertimbangan yaitu ekonomi, lingkungan dan sosial budaya. Untuk mewujudkan pengembangan wisata tersebut diperlukan kolaborasi antara pemerintah dan masyarakat yang mendiami kawasan konservasi, sehingga pengelolaan kawasan konservasi dapat dibarengi dengan pengembangan wisata yang sesuai dengan pemanfaatannya.

Teluk Weda merupakan sebuah kawasan yang terdiri dari sejumlah ekosistem memiliki potensi perikanan yang besar. Kondisi ini menyebabkan sebagian besar masyarakat menggantungkan hidup pada sumberdaya perikanan ini. Terkait dengan perencanaan kawasan konservasi dengan salah satu tujuannya adalah peningkatan pendapan, tolak ukur yang relevan untuk digunakan berupa peningkatan produksi perikanan. Peningkatan produksi perikanan ini tidak semata-mata berupa peningkatan hasil tangkap tapi diutamakan berupa diversifikasi produk perikanan.

Diversifikasi produk perikanan merupakan salah satu strategi dalam mengkomersilkan sektor perikanan di Teluk Weda. Diversifikasi selain lebih memberikan pilihan produk juga akan mmberikan nilai tambah bagi masyarakat. Nilai tambah yang dimaksud berupa adanya kegiatan supplementer bagi kegiatan perikanan seperti, pengemasan dan pemasaran sehingga menambah rantai suplai (supply chain) dalam pemanfaatan sumberdaya perikanan di Teluk Weda.

Perencanaan pengembangan kawasan pesisir dan pulau-pulau kecil di Teluk Weda diharapkan memberikan manfaat terbesar bagi masyarakat khususnya nelayan sesuai dengan kapasitas ekonomi yang sesuai dengan daya dukung serta kebijakan sosial ekonomi yang berpihak kepada kelompok yang terpinggirkan. Kebijakan sosial ekonomi perlu direkayasa-ulang, yakni diarahkan untuk kesejahteraan masyarakat khususnya nelayan sekaligus untuk menjaga kelestarian sumberdaya sehingga kegiatan sosial ekonomi dapat dipercepat dan dilakukan secara berkelanjutan. Kebijakan pembangunan perlu memberikan keberpihakan kepada masyarakat pesisir dan pulau-pulau kecil agar kelompok masyarakat yang selama ini kurang diperhatikan dapat segera mengejar ketertinggalan dari kelompok masyarakat lainnnya sehingga tujuan 
pembangunan untuk mencapai kesejahteraan yang adil bagi segenap bangsa Indonesia dapat diwujudkan.

Elemen aktivitas yang dibutuhkan guna perencanaan tindak program dalam memfasilitasi akses modal pengembangan, melaksanakan promosi keanekaragaman hayati pesisir dan pulau-pulau kecil, mendirikan sarana pelayanan dan memfasilitasi penyediaan data dan informasi merupakan perencanaan yang harus dilakukan untuk mewujudkan kawasan konservasi yang lestari dan berkelanjutan untuk masa depan masyarakat yang mendiami kawasan Teluk Weda.

\section{KESIMPULAN DAN IMPLIKASI KEBIJAKAN}

Kelembagaan pengelolaan kawasan pesisir dan pulau-pulau kecil yang perlu dipertimbangkan dalam mewujudkan sustainable development adalah pemerintah, wisatawan dan perguruan tinggi, untuk mewujudkan pengembangan wisata, produktivitas pemanfaatan sumberdaya alam, meningkatkan mutu produk perikanan, dan jumlah permodalan kegiatan perikanan tangkap, dengan membantu nelayan dalam penentuan harga perikanan, mengelola sumberdaya alam, peraturan investasi daerah dan membuat kebijakan yang konsisten.

\section{DAFTAR PUSTAKA}

Amanah Islamic Bank Rules and Regulations. 2006. Al Amanah Islamic Investment Bank of The Philippines Incorporated by The Congress of The Philippines With a Special Law Republic Act No. 6848 Officially Organized In The Philippines on April 28, 1992.

Berkes, F., P. George \& R. Preston, 1991. Co-management: The Evolution of The Theory and Practice of Joint Administration of Living Resources. Alternatives 18 (2), 12-18.

Browman \& Stergiou, 2005. Politics and Socio-Economics Of Ecosystem-Based Management of Marine Resources. Inter Research. Mar Ecol Prog Ser 300: 241-296.

Cincin-Sain, B. \& R.W. Knecht. 1998. Integrated Coastal and Ocean Management: Concepts and Practices. Washington DC: Island Press

Dahuri R., J. Rais, S.P. Ginting \& M.J. Sitepu. 2001. Pengelolaan Sumber Daya Wilayah Pesisir dan Lautan Secara Terpadu. Jakarta: Penerbit PT Pradnya Paramita.
Dutton I.M., D.G. Bengen \& J.J. Tulungen. 2001. The Challenges of Coral Reef Management in Indonesia. In Wolanski, E. (Ed). Oceanographic Processes of Coral Reefs : Physical and Biological Links in The Great Barrier Reef, CRC Press LLC, Boca Raton, Florida.

Eriyatno \& F. Sofyar. 2007. Riset Kebijakan. Metode Penelitian untuk Pascasarjana. Penerbit IPB Press.

Eriyatno. 1998. IImu Sistem. Meningkatkan Mutu dan Efektifitas Manajemen. Bogor: Penerbit IPB Press.

Hanson, A.J. 2003. Measuring Progress Towards Sustainable Development. Ocean and Coastal Management 46: 381-390.

Iwasaki-Goodman, M. 2005. Resource Management For The Next Generation: Co- Management of Fishing Resources in The Western Canadian Arctic Region. In Kishigami, N. \& J Savelle (eds.), Indigenous Use and Management of Marine Resources. Osaka: The National Museum of Ethnology 2005, p 101-21.

Kennish, M.J. 2002. Environmental Threats and Environmental Future of Estuaries. Environmental Conservation 29, 78-107

Kholil. 2005. Rekayasa Model Sistem Dinamik Pengelolaan Sampah Terpadu Berbasis Nirlimbah (Zero Waste). Studi Kasus di Jakarta Selatan (Disertasi). Program Pascasarjana Institut Pertanian Bogor, Bogor.

Murawski, S.A. 2007. Ten Myths Concerning Ecosystem Approaches to Marine Resource Management. Marine Policy 31, 681-690.

Nobre, A.M. 2009. An Ecological and Economic Assessment Methodology for Coastal Ecosystem Management. Environmental Management 44 (1): 185-204.

Nobre, A.M. \& J.G. Ferreira. 2009. Integration of Ecosystem-Based Tools to Support Coastal Zone Management. SI 56. Journal of Coastal Research: 1676-1680.

Olsen, S.B. 2002. Assessing Progress Towards The Goals of Coastal Management. Journal of Coastal Management 30: 325-345.

Ostrom, E. \& E. Schlager. 1996. The Formation of Property Rights. In Hanna et al. (Eds.), Rights to Nature, Ecological, Economic, Cultural, 
and Political Principles of Institutions for the Environment, p. 127-156. Iceland Press. Washington DC.

Saxena, J.J., P. Sushil \& P. Vrat. 1992. Hierarchy and Classification of Program Plan Element Using Interpretative Structural Modelling. System Practice Vol 12 (6): 651:670.
Singleton, S. 1998. Constructing Cooperation: The Evolution of Institutions of Co-Management. Ann Arbor: University of Michigan Press.

Supriharyono. 2000. Pelestarian dan Pengelolaan Sumber Daya Alam di Wilayah Pesisir Tropis. Jakarta: Penerbit PT Gramedia Pustaka Utama. 